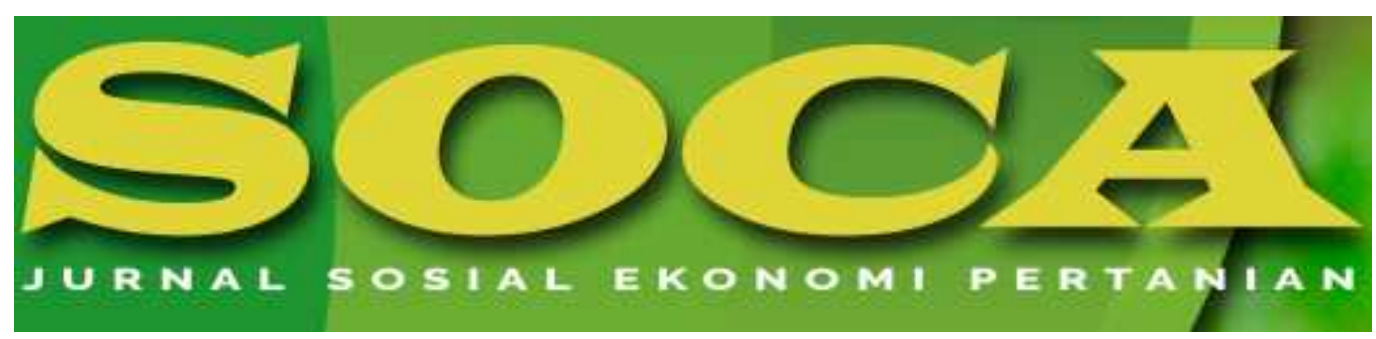

https://ojs.unud.ac.id/index.php/soca

\title{
FAKTOR-FAKTOR YANG MEMPENGARUHI KEPUASAN KERJA KARYAWAN BAGIAN PEMETIK TEH DI PT PERKEBUNAN TAMBI, UNIT PERKEBUNAN TAMBI, KABUPATEN WONOSOBO
}

\author{
Komen dan Hendrik Johannes Nadapdap \\ Fakultas Pertanian dan Bisnis Universitas Kristen Satya Wacana \\ Kota Salatiga, Jawa Tengah \\ Email korespondensi:52pastisukses@gmail.com, hendrik.nadapdap@uksw.edu, Telepon/HP:
} 082138275085

\begin{tabular}{l} 
Kata Kunci: \\
gaya \\
kepemimpinan, \\
kepuasan kerja \\
karyawan, \\
lingkungan \\
kerja, motivasi \\
kerja, PT \\
Perkebunan \\
Tambi \\
\hline
\end{tabular}

Kata Kunci: gaya kepuasan kerja karyawan, lingkungan kerja, motivasi Perkebunan Tambi 


\section{THE FACTORS THAT AFFECT THE EMPLOYEES' WORK SATISFACTION AS TEA LEAF PICKERS IN TAMBI PT PERKEBUNAN TAMBI, TAMBI PLANTANTION UNIT, WONOSOBO REGENCY}

\begin{tabular}{l} 
Keywords: \\
Leadership \\
Style, \\
Employee's \\
Work \\
Satisfaction, \\
Work \\
Environment, \\
Work \\
Motivation, Tea \\
Tambi \\
Plantation \\
Factory \\
\hline
\end{tabular}

How to Cite (APA 6th Style):

Komen, \& Nadapdap, H. J. (2019). Faktor-Faktor yang Mempengaruhi Kepuasan Kerja Karyawan Bagian Pemetik Teh di Pt Perkebunan Tambi, Unit Perkebunan Tambi, Kabupaten Wonosobo. SOCA: Jurnal Sosial Ekonomi Pertanian, 13(3), 340-354. https://doi.org/https://doi.org/10.24843/SOCA.2019.v13.i03.p05

\section{PENDAHULUAN}

Salah satu negara yang memiliki potensi kekayaan sumber daya alam yang melipah diberbagai sektor adalah Indonesia. Sektor tersebut meliputi pertanian, perkebunan, kehutanan, pertambangan, peternakan, perikanan dan lain-lain. Sektor perkebunan memiliki peluang yang cukup besar sebagai sektor yang mampu menyediakan bahan baku disektor industri, membuka lapangan pekerjaan, pendapatan bagi masyarakat dan memenuhi kebutuhan konsumsi dalam negeri serta sebagai penghasil devisa negara (BPS, 2017).

Sektor perkebunan di Indonesia yang sudah lama dibudidayakan dan mempunyai peranan dalam memberikan kontribusi pendapatan negara, masyarakat dan berdampak terhadap konservasi lingkungan adalah perkebunan teh (Rakhmawati, 2008). Selain itu, pasar komoditi teh dalam negeri masih memiliki 
peluang yang cukup besar bila diikuti dengan peningkatan kualitas mutu teh, memperluas jangkauan pemasaran ke daerah pelosok seluruh Indonesia, serta tidak kalah penting perusahaan melakukan penganekaragaman produk yang sesuai dengan keinginan atau selera masyarakat (BPS, 2017).

Tabel 1. Data Produksi Tanaman Perkebunan Teh (ribu/ton) Menurut Provinsi Periode Tahun 2013-2017.

\begin{tabular}{clccccc}
\hline \multirow{2}{*}{ No } & \multirow{2}{*}{ Provinsi } & $\mathbf{2 0 1 3}$ & $\mathbf{2 0 1 4}$ & $\mathbf{2 0 1 5}$ & $\mathbf{2 0 1 6}$ & $\mathbf{2 0 1 7}$ \\
\cline { 3 - 7 } & & 107.30 & 105.30 & 90.60 & 76.30 & 98.90 \\
\hline 1 & Jawa Barat & 13.89 & 11.50 & 11.40 & 12.90 & 8.40 \\
2 & Jawa Tengah & 5.27 & 12.80 & 7.10 & 10.60 & 7.00 \\
3 & Sumatera Utara & 8.62 & 8.00 & 8.00 & 7.70 & 8.00 \\
4 & Sumatera Barat & 2.67 & 6.90 & 6.90 & 6.20 & 6.90 \\
5 & Jawa Timur & & & & & \\
\hline
\end{tabular}

Sumber : BPS yang (diolah), 2019

Penurunan maupun peningkatan produksi teh di Provinsi Jawa Tengah tentu disebabkan oleh berbagai faktor produksi, salah satunya faktor tenaga kerja (Damanik, 2015). Perkebunan teh yang luas tentu memerlukan jumlah tenaga kerja yang banyak untuk mengelola, mempermudah pekerjaan dan mencapai target produksi secara maksimal. Selain itu, perusahaan perlu mempertahanan dan meningkatkan kinerja setiap karyawan. Kinerja karyawan akan terpenuhi dengan memberikan rasa kepuasan kerja. Ketika karyawan puas dalam bekerja, maka karyawan akan memberikan kinerja secara maksimal dan sebaliknya kinerja karyawan kurang maksimal jika tidak merasakan kepuasan dalam melaksanakan pekerjaan. Kepuasan kerja merupakan keadaan yang menyatakan perasaan karyawan terhadap pekerjaan yang mereka lakukan (Handoko, 2002).

Faktor yang mempengaruhi kepuasan kerja karyawan adalah motivasi kerja dan budaya organisasi. Menurut Brahmasari dan Suprayetno (2008) dalam penelitiannya menyatakan " motivasi kerja dan budaya organisasi berpengaruh signifikan terhadap kepuasan kerja karyawan." Semakin besar motivasi kerja yang dimiliki karyawan dan budaya organisasi yang baik diterapkan perusahaan dalam melaksanakan pekerjaan maka akan berdampak terhadap kepuasan kerja. Menurut Mariam (2009) menyatakan "gaya kepemimpinan berpengaruh signifikan terhadap kepuasan kerja karyawan." Artinya semakin baik gaya kepemimpinan yang diterapkan perusahaan akan meningkatkan kepuasan kerja karyawan. Selain itu, fasilitas kerja merupakan faktor yang dapat mempengaruhi kepuasan kerja. Menurut Dahlius dan Ibrahim (2016) menyatakan "fasilitas kerja berpengaruh signifikan terhadap kepuasan kerja karyawan." Artinya semakin lengkap fasilitas kerja yang diberikan perusahaan kepada karyawan dalam menunjung pekerjaan dapat meningkatkan kepuasan kerja karyawan. Lingkungan kerja yang mendukung bisa bekerja membuat karyawan lebih nyaman dalam melaksanakan pekerjaan. Menurut Devino (2017) menyatakan "lingkungan kerja berpengaruh signifikan terhadap kepuasan kerja karyawan." Artinya samakin baik lingkungan kerja yang dirasakan karyawan dapat meningkatkan kepuasan kerja karyawan. Dari hasil penelitian diatas, menunjukkan bahwa faktor yang dapat mempengaruhi kepuasan meliputi motivasi kerja, budaya organisasi, gaya kepemimpinan, fasilitas kerja dan lingkungan kerja. Oleh karena itu, peneliti tertarik untuk melakukan penelitian di PT Perkebunan Tambi, Unit Perkebunan Tambi, Kabupaten Wonosobo. 
PT Perkebunan Tambi merupakan perusahaan Perkebunan Besar Swasta yang bergerak dibidang agribisnis teh yang berlokasi di Kabupaten Wonosobo. PT Perkebunan Tambi memiliki tiga unit produksi, yaitu unit perkebunan Tambi, Bedakah dan Tanjung Sari. Unit Perkebunan Tambi dan Bedakah memproduksi teh hitam, sedangkan Unit Perkebunan Tanjung Sari memproduksi teh hijau. Unit Perkebunan Tambi memiliki luas lahan 248.67 Ha (Tambi, 2019). Di Unit Perkebunan Tambi masih terdapat karyawan yang bekerja sebagai pemetik daun teh dengan masa kerja yang sudah lama.

Penelitian ini bertujuan; 1) mendiskripsikan kepuasan kerja karyawan bagian pemetik teh di PT Perkebunan Tambi, Unit Perkebunan Tambi, Kabupaten Wonosobo, dan 2) menganalisis pengaruh faktor motivasi kerja, budaya organisasi, gaya kepemimpinan, fasilitas kerja dan lingkungan kerja terhadap kepuasan kerja karyawan bagian pemetik teh di PT Perkebunan Tambi, Unit Perkebunan Tambi, Kabupaten Wonosobo.

\section{METODE PENELITIAN}

\section{Tempat dan Waktu Penelitian}

Penelitian ini dilaksanakan di PT Perkebunan Tambi, Unit Perkebunan Tambi, Kabupaten Wonosobo yang dimulai pada bulan Januari s/d Februari 2019.

\section{Jenis dan Metode Penelitian}

Jenis penelitian yang digunakan dalam penelitian ini adalah deskriptif kuantitatif, yaitu penelitian yang berfokus pada permasalahan yang sedang terjadi (Nazir, 2011). Adapun metode penelitian yang digunakan adalah survei, yaitu penelitian yang dilakukan pada individu yang dianggap bisa mewakili untuk memberikan gambaran terhadap populasi yang diteliti (Faisal, 2007).

\section{Teknik Pengambilan Sampel}

Penelitian ini menggunakan pendekatan probability sampling dengan teknik simple random sampling, yaitu pengambilan sampel yang dilakukan secara acak tanpa memperhatikan tingkatan tertentu dalam sebuah populasi (Sugiyono, 2013). Responden yang menjadi sampel dalam penelitian ini adalah karyawan harian tetap bagian pemetik teh yang berjumlah 57 orang yang diperoleh melalui perhitungan dengan rumus slovin:

Keterangan:

$$
n=\frac{\mathrm{N}}{\mathrm{N}(\mathrm{e})^{2}}=\frac{1}{1 \quad(\mathrm{U}, 1)^{2}}=57
$$

$n=$ Jumlah Sampel

$\mathrm{N}=$ Jumlah Sampel

$e=$ Standar Error $10 \%$ atau 0,1

\section{Teknik Pengumpulan Data}

Teknik pengumpulan data yang digunakan dalam penelitian ini adalah wawancara, observasi, kuisioner dan studi pustaka. 


\section{Analisis Data}

\section{Analisis Deskriptif}

Analisis deskriptif dalam penelitian ini bertujuan untuk mendiskripsikan kepuasan kerja karyawan bagian pemetik teh di PT Perkebunan Tambi, Unit Perkebunan Tambi, Kabupaten Wonosobo.

\section{Analisis Regresi Linear Berganda}

Analisis regresi linear berganda dalam penelitian ini bertujuan untuk mengetahui pengaruh faktor motivasi kerja, budaya organisasi, gaya kepemimpinan, fasilitas kerja dan lingkungan kerja terhadap kepuasan kerja karyawan bagian pemetik teh di PT Perkebunan Tambi, Unit Perkebunan Tambi, Kabupaten Wonosobo.

Persamaan regresi linear berganda yang digunakan dalam penelitian ini sebagai berikut :

Keterangan:

$$
Y=\beta_{0}+\beta_{1} X_{1}+\beta_{2} X_{2}+\beta_{3} X_{3}+\beta_{4} x_{4}+\beta_{5} X_{5}+\varepsilon
$$

$\mathrm{Y} \quad=$ Kepuasan Kerja Karyawan

$\mathrm{X}_{1} \quad=$ Motivasi Kerja

$\mathrm{X}_{2} \quad$ = Budaya Organisasi

$\mathrm{X}_{3} \quad=$ Gaya Kepemimpinan

$\mathrm{X}_{4} \quad=$ Fasilitas Kerja

$\mathrm{X}_{5} \quad$ = Lingkungan Kerja

$\beta_{\mathrm{u}} \quad=$ Intersep

$\beta_{1-5}=$ Koefisien regresi dari $X_{1}$ hingga $X_{5}$

$\varepsilon \quad=$ Error

Validitas adalah suatu derajat ketepatan alat ukur penelitian tentang isi atau arti sebenarnya yang diukur (Umar, 2005). Reliabilitas adalah derajat ketepatan, ketelitian atau keakuratan yang ditunjukkan oleh instrumen pengukuran (Umar, 2005). Uji normalitas digunakan untuk menguji apakah dalam model regresi varibel terikat dan variabel bebas mempunyai distribusi normal atau tidak normal. Uji multikolinearitas bertujuan untuk menguji apakah dalam model regresi ditemukan adanya korelasi antar variabel bebas. Suatu model tidak terjadi masalah multikoliearitas, apabila nilai VIF $<10$ dan Tolarence $>0,10$ (Ghozali, 2012). Uji Heteroskedastisitas digunakan untuk menguji apakah dalam model regresi terjadi ketidaksamaan variance dari residual dari satu pengematan ke pengamatan lainnya (Ghozali, 2012). Uji t digunakan untuk menguji seberapa jauh pengaruh variabel bebas secara individu menjelaskan variabel terikat (Ghozali, 2012). Uji F digunakan untuk mengetahui apakah semua variabel bebas mempunyai pengaruh secara simultan (bersama-sama) terhadap variabel terikat (Ghozali, 2012). Uji $R$ square $\left(\mathrm{R}^{2}\right)$ digunakan untuk mengukur seberapa jauh kemampuan model dalam menerangkan variasi terhadap variabel terikat. Jika nilai $\mathrm{R}^{2}$ kecil, maka kemapuan variabel bebas dalam menerangkan amat terbatas terhadap variabel terikat. Sedangkan nilai $\mathrm{R}^{2}$ mendekati 1, menunjukkan bahwa kemampuan variabel bebas mampu menerangkan hampir semua informasi yang dibutuhkan untuk memprediksi variasi variabel terikat (Ghozali, 2012). 


\section{HASIL DAN PEMBAHASAN}

\section{Karakteristik Responden}

Pada tabel 2. karakteristik responden diatas, menunjukkan bahwa karyawan bagian pemetik di PT Perkebunan Tambi, Unit Perkebunan Tambi, Kabupaten Wonosobo didominasi oleh rentang usia antara 37 - 40 dan 49 - 52 tahun sebanyak 11 orang $(19,3 \%)$, jenis kelamin perempuan sebanyak 56 orang $(98,2 \%)$ dan tingkat pendidikan lulusan SD sebanyak 47 orang $(82,5 \%)$ serta dengan lama bekerja antara $27-32$ tahun sebanyak 17 orang $(29,8 \%)$.

Tabel 2. Karakteristik Responden

\begin{tabular}{|c|c|c|c|}
\hline No & $\begin{array}{c}\text { Responden Berdasarkan } \\
\text { Usia (Tahun) }\end{array}$ & $\begin{array}{l}\text { Frekuensi } \\
\text { (Orang) }\end{array}$ & $\begin{array}{c}\text { Persentase } \\
\text { (\%) }\end{array}$ \\
\hline 1 & $29-32$ & 2 & 3,5 \\
\hline 2 & $33-36$ & 5 & 8,8 \\
\hline 3 & $37-40$ & 11 & 19,3 \\
\hline 4 & $41-44$ & 9 & 15,8 \\
\hline 5 & $45-48$ & 10 & 17,5 \\
\hline 6 & $49-52$ & 11 & 19,3 \\
\hline \multirow[t]{2}{*}{7} & $53-56$ & 9 & 15,8 \\
\hline & $\begin{array}{c}\text { Total } \\
\text { Jenis Kelamin }\end{array}$ & 57 & 100 \\
\hline 8 & Perempuan & 56 & 98,2 \\
\hline \multirow[t]{2}{*}{9} & Laki-laki & 1 & 1,8 \\
\hline & $\begin{array}{c}\text { Total } \\
\text { Tingkat Pendidikan }\end{array}$ & 57 & 100 \\
\hline 10 & Tidak Tamat SD & 6 & 10,5 \\
\hline 11 & $\mathrm{SD}$ & 47 & 82,5 \\
\hline 12 & SLTP/SMP & 3 & 5,3 \\
\hline \multirow[t]{2}{*}{13} & SLTA & 1 & 1,8 \\
\hline & $\begin{array}{c}\text { Total } \\
\text { Lama Bekerja (Tahun) }\end{array}$ & 57 & 100 \\
\hline 14 & $3-8$ & 8 & 14,0 \\
\hline 15 & $9-14$ & 6 & 10,5 \\
\hline 16 & $15-20$ & 11 & 19,3 \\
\hline 17 & $21-26$ & 7 & 12,3 \\
\hline 18 & $27-32$ & 17 & 29,8 \\
\hline 19 & $33-38$ & 5 & 8,8 \\
\hline \multirow[t]{2}{*}{20} & $39-44$ & 3 & 5,3 \\
\hline & Total & 57 & 100 \\
\hline
\end{tabular}

Sumber: data primer (diolah), 2019

\section{Uji Validitas}

Pada tabel 3. uji validitas diatas, menunjukkan bahwa item instrumen penelitian dari variabel motivasi kerja, budaya organisasi, gaya kepemimpinan, fasilitas kerja, lingkungan kerja dan kepuasan kerja karyawan dikatakan valid, karena memiliki $r$-hitung $>r$-tabel. Hal ini sesuai dengan pendapat Arikunto (2010) menyatakan bahwa "suatu instrumen penelitian dikatakan valid, jika memiliki nilai pearson correlation $r_{\text {hitung }}>r_{\text {tabel." }}$ 
Tabel 3. Uji Validitas

\begin{tabular}{lccc}
\hline $\begin{array}{c}\text { Variabel } \\
\text { Penelitian }\end{array}$ & $\begin{array}{c}\text { Item } \\
\text { Pertanyaan }\end{array}$ & r-Hitung & $\begin{array}{c}\text { r-Tabel } \\
\mathbf{( 0 , 0 5 \% )}\end{array}$ \\
\hline Motivasi Kerja (X1) & X1.1 & 0,616 & 0,260 \\
X1.2 & 0,685 & 0,260 \\
Budaya Organisasi (X2) & X1.3 & 0,824 & 0,260 \\
& X2.1 & 0,645 & 0,260 \\
& X2.2 & 0,816 & 0,260 \\
Xaya Kepemimpinan (X3) & X2.3 & 0,819 & 0,260 \\
& X2.5 & 0,389 & 0,260 \\
& X3.1 & 0,366 & 0,760 \\
Fasilitas Kerja (X4) & X3.2 & 0,492 & 0,260 \\
& X3.3 & 0,701 & 0,260 \\
& X3.4 & 0,800 & 0,260 \\
& X4.1 & 0,419 & 0,260 \\
Lingkungan Kerja (X5) & X4.2 & 0,799 & 0,260 \\
& X4.3 & 0,679 & 0,260 \\
& X4.4 & 0,763 & 0,260 \\
& X4.5 & 0,498 & 0,260 \\
& X5.1 & 0,631 & 0,260 \\
& X5.2 & 0,746 & 0,260 \\
& X5.3 & 0,548 & 0,260 \\
& X5.4 & 0,434 & 0,260 \\
& X5.5 & 0,837 & 0,260 \\
& Y1.1 & 0,718 & 0,260 \\
& Y1.2 & 0,740 & 0,260 \\
& Y1.3 & 0,550 & 0,260 \\
& Y1.4 & 0,470 & 0,260 \\
& Y1.5 & 0,723 & 0,260 \\
\hline
\end{tabular}

Sumber: data primer (diolah), 2019

\section{Reliabilitas}

Pada tabel 4. uji reliabilitas diatas, menunjukkan bahwa variabel motivasi kerja, budaya organisasi, gaya kepemimpinan, fasilitas kerja, lingkungan kerja dan kepuasan kerja karyawan dikatakan reliabel, karena memiliki nilai Cronbach's Alpha $>0,06$. Hal ini sesuai dnegan pendapat Ghozali (2012) menyatakan bahwa "suatu kuisioner penelitian dinyatakan reliabel, jika memiliki nilai Cronbach's Alpha > 0,06."

Tabel 4. Uji Reliabilitas

\begin{tabular}{lc}
\hline \multicolumn{1}{c}{ Variabel Penelitian } & Cronbach's Alpha \\
\hline Motivasi Kerja (X1) & 0,620 \\
Budaya Organisasi (X2) & 0,625 \\
Gaya Kepemimpinan (X3) & 0,656 \\
Fasilitas Kerja (X4) & 0,615 \\
Lingkungan Kerja (X5) & 0,658 \\
Kepuasan Kerja Karyawan(X5) & 0,601
\end{tabular}

Sumber: data primer (diolah), 2019 


\section{Uji Asumsi Klasik}

\section{Uji Normalitas}

Pada tabel 5. uji normalitas diatas, menujukkan variabel motivasi kerja, budaya organisasi, gaya kepimpinan, fasilitas kerja dan lingkungan kerja dikatakan berdistribusi normal, karena memiliki nilai Asymp. Sig (2-tailed) > Signifikansi 0,05. Hal ini sesuai pendapat Lufitasari (2014) menyatakan bahwa suatu data penelitian dikatakan berdistribusi normal, jika memiliki nilai Asymp. Sig. (2-tailed) > 0,05 atau $>5 \%$.

Tabel 5. Uji Normalitas menggunakan uji Kolmogrov-Smirnov

\begin{tabular}{cc}
\hline & Unstandardized Residual \\
\hline Asymp. Sig (2-tailed) & 0,200 \\
\hline
\end{tabular}

Sumber: data primer (diolah), 2019

\section{Uji Multikolinearitas}

Pada tabel 6. uji multikolinearitas diatas, menunjukkan bahwa motivasi kerja, budaya organisasi, gaya kepemimpinan, fasilitas kerja dan lingkungan kerja tidak terjadi masalah multikolinearitas karena memiliki nilai Tolarence $>0,1$ dan VIF < 10. Hal ini sesuai dengan pendapat Ghozali (2012) menyatakan bahwa "suatu model tidak terjadi masalah multikoliearitas, apabila nilai Tolarence $>0,1$ dan $V I F<10$."

Tabel 6. Uji Multikolinearitas

\begin{tabular}{lcc}
\hline Variabel Penelitian & Tolarence & VIF \\
\hline Motivasi Kerja (X1) & 0,341 & 2,934 \\
Budaya Organisasi (X2) & 0,342 & 2,925 \\
Gaya Kepemimpinan (X3) & 0,444 & 2,254 \\
Fasilitas Kerja (X4) & 0,495 & 2,022 \\
Lingkungan Kerja (X5) & 0,368 & 2,717 \\
\hline
\end{tabular}

Sumber: data primer (diolah), 2019

\section{Uji Heteroskedastisitas}

Pada tabel 7. uji heteroskedastisitas diatas, menunjukkan bahwa variabel motivasi kerja, budaya organisasi, gaya kepemimpinan, fasilitas kerja dan lingkungan kerja tidak terjadi masalah heteroskedastisitas karena memiliki nilai signifikansi $>0,05$. Hal ini sesuai dengan pendapat Priyatno (2013) menyatakan bahwa "suatu model regresi tidak terjadi masalah heteroskedastisitas, jika memiliki nilai signifikansi > 0,05."

Tabel 7. Uji Heteroskedastisitas Menggunakan Uji Glejser

\begin{tabular}{lrcc}
\hline \multicolumn{1}{c}{ Variabel Penelitian } & B & Std. Error & Signifikansi \\
\hline Motivasi Kerja (X1) & 0,045 & 0,066 & 0,499 \\
Budaya Organisasi (X2) & $-0,028$ & 0,073 & 0,700 \\
Gaya Kepemimpinan (X3) & 0,021 & 0,061 & 0,733 \\
Fasilitas Kerja (X4) & $-0,052$ & 0,038 & 0,178 \\
Lingkungan Kerja (X5) & $-0,034$ & 0,059 & 0,566
\end{tabular}

Sumber: data primer (diolah), 2019 


\section{PEMBAHASAN}

\section{Kepuasan Kerja Karyawan}

Pada tabel 8. distribusi jawaban responden diatas, menunjukkan bahwa karyawan bagian pemetik teh merasa puas bekerja di PT Perkebunan Tambi, Unit Pekebunan Tambi. Hal ini terlihat dari pada item pernyataan Y1.1, dimana sebanyak 40 responden menyatakan Sangat Setuju (70,2\%) bahwa kepuasan kerja yang dirasakan karyawan karena pekerjaan sebagai pemetik teh mampu memberikan tantangan tersendiri bagi karyawan dalam melaksanakan pekerjaan setiap harinya. Karyawan merasa dengan pekerjaan yang memberikan tantangan setiap harinya, maka muncul rasa ketidakbosanan karyawan terhadap pekerjaan sehingga menyebabkan karyawan masih bertahan sebagai pemetik teh. Selain itu, pada item Y1.2, dimana sebanyak 29 responden menyatakan Setuju $(50,9 \%)$ perusahaan memberikan upah sudah sesuai pekerjaan yang karyawan laksanakan. Besar kecil imbalan yang diterima setiap karyawan tergantung dari seberapa besar karyawan memperoleh hasil petikan teh setelah dilakukan penimbangan setiap harinya. Pada item pernyataan Y1.3 sebanyak 48 responden menyatakan Setuju $(84,2 \%)$, bahwa kepuasan kerja karyawan disebabkan oleh keadaan tempat kerja mendukung karyawan. Dengan keadaan tempat kerja yang mendukung, karyawan merasa lebih nyaman dan bekerja secara maksimal dalam melaksanakan pekerjaan. Pada item pernyataan Y1.4 sebanyak 41 responden menyatakan Sangat Setuju (71,9\%) bahwa kepuasan kerja karyawan, karena rekan sesama pemetik teh saling membantu satu sama lain. Pada item pernyataan Y1.5 sebanyak 47 responden menyatakan Sangat Setuju $(82,5 \%)$ bahwa kepuasan kerja karyawan karena pekerjaan sebagai pemetik teh sesuai dengan keinginan dari karyawan sehingga karyawan menikmati dan memberikan kontribusi secara maksimal.

Tabel 8. Distribusi Jawaban Responden Variabel Kepuasan Kerja Karyawan

\begin{tabular}{|c|c|c|c|c|c|c|c|c|c|c|c|c|c|}
\hline \multirow{3}{*}{ Item } & \multicolumn{10}{|c|}{ Jawaban Responden } & & & \multirow{3}{*}{ Modus } \\
\hline & \multicolumn{2}{|c|}{$\begin{array}{c}\text { STS } \\
(1)\end{array}$} & \multicolumn{2}{|c|}{$\begin{array}{l}\text { TS } \\
(2)\end{array}$} & \multicolumn{2}{|c|}{$\begin{array}{c}\mathrm{N} \\
(3)\end{array}$} & \multicolumn{2}{|c|}{$\begin{array}{c}S \\
(4) \\
\end{array}$} & \multicolumn{2}{|c|}{$\begin{array}{l}\text { SS } \\
\text { (5) }\end{array}$} & \multicolumn{2}{|c|}{ Total } & \\
\hline & $\mathrm{F}$ & $\%$ & $\mathrm{~F}$ & $\%$ & $\mathrm{~F}$ & $\%$ & $\mathrm{~F}$ & $\%$ & $\mathrm{~F}$ & $\%$ & $\mathrm{~F}$ & $\%$ & \\
\hline $\mathrm{Y} 1.1$ & 0 & 0 & 0 & 0 & 2 & 3,5 & 15 & 26,3 & 40 & 70,2 & 57 & 100 & 5 \\
\hline $\mathrm{Y} 1.2$ & 0 & 0 & 3 & 5,3 & 4 & 7,0 & 29 & 50,9 & 21 & 36,8 & 57 & 100 & 4 \\
\hline Y1.3 & 0 & 0 & 1 & 1,8 & 4 & 7,0 & 48 & 84,2 & 4 & 7,0 & 57 & 100 & 4 \\
\hline Y1.4 & 0 & 0 & 0 & 0 & 1 & 1,8 & 15 & 26,3 & 41 & 71,9 & 57 & 100 & 5 \\
\hline Y1.5 & 0 & 0 & 0 & 0 & 0 & 0 & 10 & 17,5 & 47 & 82,5 & 57 & 100 & 5 \\
\hline
\end{tabular}

Sumber : data primer (diolah), 2019

\section{Anlisis Regresi Linear Berganda}

Berdasarkan Tabel 9. berikut, maka diperoleh persamaan regresi linear berganda sebagai berikut:

$$
Y=1,756+0,349 X+0,284 X_{2}+0,167 X_{3}-0,009 X_{4}+0,234 X_{5}
$$


Tabel 9. Analisi Regresi Linear Berganda Faktor-Faktor Yang Mempengaruhi Kepuasan Kerja Karyawan

\begin{tabular}{lcccc}
\hline \multicolumn{1}{c}{ Variabel Penelitian } & B & Std. Error & t $_{\text {hitung }}$ & Sig. \\
\hline (Constant) & 1,756 & 1,714 & 1,025 &, 310 \\
Motivasi Kerja (X1) & 0,349 & 0,111 & 3,141 & $0,003^{*}$ \\
Budaya Organisasi (X2) & 0,284 & 0,124 & 2,295 & $0,026^{*}$ \\
Gaya Kepemimpinan (X3) & 0,167 & 0,103 & 1,619 & $0,112^{\mathrm{ns}}$ \\
Fasilitas Kerja (X4) & $-0,009$ & 0,065 & $-0,140$ & $0,889^{\mathrm{ns}}$ \\
Lingkungan Kerja (X5) & 0,234 & 0,099 & 2,363 & $0,022^{*}$ \\
& & & & \\
F-hitung & 36,502 & & & \\
R & 0,884 & & & \\
R-Square & 0,782 & & & \\
Adjusted R-Square & 0,782 & & & \\
\hline
\end{tabular}

Keterangan: * Nyata pada signifikan $5 \%(0,05)$

ns non signifikan

Sumber: data primer (diolah), 2019

\section{Uji Parsial (Uji t)}

Uji $t$ bertujuan untuk mengetahui pengaruh variabel motivasi kerja, budaya organisasi, gaya kepemimpinan, fasilitas kerja dan lingkungan kerja terhadap kepuasan kerja karyawan secara parsial. Kemudian hasil t-Hitung yang diperoleh akan dibandingkan dengan nilai t-Tabel 1,673. Pada tabel 9. analisis analisis regresi linear berganda diatas, diperoleh kesimpulan sebagai berikut :

1. Secara parsial menunjukkan motivasi kerja memiliki pengaruh yang signifikan terhadap kepuasan kerja karyawan bagian pemetik teh di PT Perkebunan Tambi, Unit Perkebunan Tambi, Kabupaten Wonosobo karena nilai t-Hitung $3.141>$ t-Tabel 1.673 dan Sig. 0,003 < 0,05 sehingga hipotesis penelitian pertama HO ditolak, sedangkan $\mathrm{H} 1$ diterima.

2. Secara parsial menunjukkan budaya organisasi memiliki pengaruh yang signifikan terhadap kepuasan kerja karyawan bagian pemetik teh di PT Perkebunan Tambi, Unit Perkebunan Tambi, Kabupaten Wonosobo karena nilai $\mathrm{t}$-Hitung 2,295 > t-Tabel 1,673 dan Sig. 0,026 < 0,05 sehingga hipotesis penelitian kedua HO ditolak, sedangkan $\mathrm{H} 1$ diterima.

3. Secara parsial menunjukkan gaya kepemimpinan tidak memiliki pengaruh yang signifikan terhadap kepuasan kerja karyawan bagian pemetik teh di PT Perkebunan Tambi, Unit Perkebunan Tambi, Kabupaten Wonosobo karena nilai $\mathrm{t}$-Hitung $1,619<\mathrm{t}$-Tabel 1,673 dan Sig. 0,112>0,05 sehingga hipotesis penelitian ketiga $\mathrm{HO}$ diterima, sedangkan $\mathrm{H} 1$ ditolak.

4. Secara parsial menunjukkan fasilitas kerja tidak memiliki pengaruh yang signifikan terhadap kepuasan kerja karyawan bagian pemetik teh di PT Perkebunan Tambi, Unit Perkebunan Tambi, Kabupaten Wonosobo karena nilai $\mathrm{t}$-Hitung $-0,140<\mathrm{t}$-Tabel 1,673 dan Sig. 0,889 > 0,05 sehingga hipotesis penelitian keempat HO diterima, sedangkan $\mathrm{H} 1$ ditolak. 
5. Secara parsial menunjukkan lingkungan kerja memiliki pengaruh yang signifikan terhadap kepuasan kerja karyawan bagian pemetik teh di PT Perkebunan Tambi, Unit Perkebunan Tambi, Kabupaten Wonsobo karena nilai t-Hitung 2,363 > t-Tabel 1,673 dan Sig. 0,022 < 0,05 sehingga hipotesis penelitian kelima HO ditolak, sedangkan $\mathrm{H} 1$ diterima.

\section{Uji Simultan (Uji F)}

Uji $\mathrm{F}$ bertujuan untuk mengetahui pengaruh variabel motivasi kerja, budaya organisasi, gaya kepemimpinan, fasilitas kerja dan lingkungan kerja secara simultan (bersama-sama) terhadap kepuasan kerja karyawan. Kemudian hasil $\mathrm{F}_{\text {hitung }}$ yang diperoleh akan dibandingkan dengan nilai $F_{\text {tabel }}$ 2.40. Pada tabel 9. diatas, diketahui nilai $\mathrm{F}_{\text {-hitung }}$ 36,502 $>\mathrm{F}_{\text {-Tebel }}$ 2,40 dan Sig. 0,000 <0,05, artinya variabel motivasi kerja, budaya organisasi, gaya kepemimpinan, fasilitas kerja dan lingkungan kerja secara simultan (bersama-sama) memiliki pengaruh yang signifikan terhadap kepuasan kerja karyawan bagian pemetik teh di PT Perkebunan Tambi, Unit Perkebunan Tambi, Kabupaten Wonosobo.

\section{Uji R $\mathbf{R}^{2}$}

Pada tabel 9. diatas, diketahui nilai $R$-Square 0,782 yang berarti $78,2 \%$ kepuasan kerja karyawan dijelaskan oleh variabel motivasi kerja, budaya organisasi, gaya kepimpinan, fasilitas kerja dan lingkungan kerja. Sementara 21,8\% dijelaskan variabel lain yang tidak termasuk dalam penelitian ini.

\section{Pengaruh Motivasi Kerja (X1) Terhadap Kepuasan Kerja Karyawan (Y)}

Secara parsial menunjukkan motivasi kerja memiliki pengaruh yang signifikan terhadap kepuasan kerja karyawan bagian pemetik teh di PT Perkebunan Tambi, Unit Perkebunan Tambi, Kabupaten Wonosobo karena t-Hitung 3,141>t-Tabel 1,673 dan Sig. 0,003 < 0,05 serta dengan koefisien regresi 0,349. Artinya semakin besar motivasi kerja yang dimiliki yang disebabkan oleh dorongan dalam diri karyawan maupun perusahaan, maka akan berdampak terhadap kepuasan kerja yang dirasakan karyawan. Penelitian ini sejalan dengan penelitian Brahmasari dan Suprayetno (2008) menyatakan bahwa "motivasi kerja berpengaruh positif dan signifikan terhadap kepuasan kerja karyawan."

Karyawan termotivasi bekerja sebagai pemetik teh di Unit Perkebunan Tambi disebabkan oleh kebijakan dan peraturan perusahaan, dimana karyawan merasa perusahaan memberikan kebijakan dan peraturan yang mempermudah mereka dalam melaksanakan pekerjaan. Imbalan yang diperoleh karyawan dari perusahaan sesuai dengan pekerjaan yang karyawan lakukan. Besar kecil imbalan yang diperoleh karyawan tergantung dari produktivitas kerja karyawan sendiri. Pekerjaan sebagai pemetik teh memiliki tantangan secara tersendiri bagi karyawan sehingga karyawan merasa dengan adanya tantangan pekerjaan tersebut timbul rasa ketidakbosanan karyawan terhadap pekerjaan. Ketika rasa ketidakbosanan karyawan muncul, maka karyawan merasakan kepuasan dalam bekerja dan lebih menikmati pekerjaan yang mereka lakukan serta termotivasi untuk terus bekerja setiap harinya.

Selain itu, karyawan termotivasi bekerja karena tempat kerja yang lebih mudah dijangkau dan pekerjaan sebagai pemetik teh merupakan salah satu peluang pekerjaan utama yang harus dimanfaatkan bagi karyawan perempuan untuk membantu perekonomian keluarga disamping suami berusahatani. Bangun (2012), 
menyatakan motivasi kerja merupakan suatu keadaan yang menyebabkan seseorang bergerak untuk mencapai tujuan yang diinginkan baik berasal dari.

\section{Pengaruh Budaya Organisasi $\left(\mathbf{X}_{2}\right)$ Terhadap Kepuasan Kerja Karyawan ( $\left.Y\right)$}

Secara parsial menunjukkan budaya organisasi memiling pengaruh yang signifikan terhadap kepuasan kerja karyawan bagian pemetik teh di PT Perkebunan Tambi, Unit Perkebunan Tambi, Kabupaten Wonosobo karena t-Hitung 2,295 > t-Tabel 1,673 dan Sig. 0,026<0,05 serta dengan koefisien regresi 0,284. Artinya semakin baik budaya organisasi yang diterapkan perusahaan dalam melaksanakan pekerja, maka akan berdampak terhadap kepuasan kerja yang dirasakan karyawan. Penelitian ini sejalan dengan penelitian Brahmasari dan Suprayetno (2008) menyatakan bahwa "budaya organisasi berpengaruh positif dan signifikan terhadap kepuasan kerja karyawan."

Budaya organisasi di Unit Perkebunan Tambi seperti karyawan dituntut untuk bersikap jujur, bertanggung jawab serta memenuhi peraturan dan melaksanakan nilai-nilai atau pedoman yang dipegang teguh perusahaan dalam melaksanakan pekerjaan. Dalam proses pemetikan pucuk teh, karyawan harus mematuhi peraturan tentang standar petikan untuk memperoleh pucuk teh yang berkualitas dan menyelesaikan pekerjaan yang sudah dibeban oleh pembimbing petik sebelum truck daun tiba. Karyawan merasa dengan adanya standar petik untuk memperoleh pucuk teh yang berkualitas memacu karyawan untuk terus bekerja dengan hatihati. Dengan begitu karyawan menilai bahwa bekerja sebagai pemetik teh tidak memerlukan kepandaian tertentu saja, tetapi yang lebih penting adalah keterampilan dari individu karyawan. Heriyanti (2007), mendefinisikan budaya organisasi merupakan suatu pedoman yang digunakan karyawan dalam bersikap dan bertindak untuk mencapai tujuan organisasi.

Selain itu, di Unit Perkebunan Tambi memiliki Periska (Persatuan Istri Karyawan) dan Penguyuban Kebun. Peguyuban kebun merupakan wadah tempat berkomunikasi untuk saling bertukar informasi dan keluh kesah yang dirasakan karyawan baik sesama rekan kerja pemetik teh, pembimbing atau kepada perusahaan mengenai apa yang harus diperbaiki kedepannya. Lewat peguyuban kebun karyawan merasa terbantu bukan hanya untuk menyelesaikan pekerja, tetapi hubungan sosial antara sesama rekan kerja pemetik teh dan atasan terjalin lebih baik.

\section{Pengaruh Gaya Kepemimpinan (X3) Terhadap Kepuasan Kerja Karyawan (Y)}

Secara parsial menunjukkan gaya kepemimpinan memiliki pengaruh yang signifikan terhadap kepuasan kerja karyawan bagian pemetik teh di PT Perkebunan Tambi, Unit Perkebunan Tambi, Kabupaten Wonosobo karena t-Hitung 1,619< t-Tabel 1,673 dan Sig. 0,112>0,05 serta dengan koefisien regresi 0,617. Artinya semakin baik gaya kepemimpinan yang diterapkan atasan kepada bawahan, maka tidak akan memberikan dampak terhadap kepuasan kerja karyawan. Penelitian ini tidak sejalan dengan penelitian Mariam (2009) menyatakan bahwa "gaya kepemimpinan berpengaruh terhadap kepuasan kerja karyawan."

Gaya kepemimpinan merupakan strategi yang digunakan pemimpin untuk mempengaruhi bawahannya dalam mencapai suatu tujuan tertentu (Prasetiyo, 2014). Sikap dan tindakan seorang karyawan dalam melaksanakan pekerjaan sangat tergantung peranan atasan. Dengan adanya kebijakan rotasi kerja pembimbing petik disetiap blok yang diterapkan perusahaan menyebabkan perubahan yang berhubungan dengan karyawan. Setiap pembimbing petik memiliki 
gaya kepemimpinan yang berbeda-beda dalam melakukan pendekatan dan berhubungan dengan setiap karyawan baik dalam menjelaskan pentingnya pekerjaan kepada setiap karyawan, membantu karyawan dalam menyelesaikan masalah pekerjaan, memberikan kesempatan kepada karyawan dalam menyelesaikan pekerjaan dengan cara sendiri dan menghargai pekerjaan yang sudah karyawan lakukan. Hal ini membuat karyawan merasa peranan atasan menjadi kurang maksimal sehingga gaya kepemimpinan tidak memberikan dampak terhadap kepuasan kerja karyawan. Penelitian ini didukung oleh Hartono (2018), dalam penelitiannya menyatakan bahwa kepemimpinan tidak berpengaruh signifikan terhadap kepuasan kerja karyawan.

\section{Pengaruh Fasilitas Kerja (X4) Terhadap Kepuasan Kerja Karyawan (Y)}

Secara parsial menunjukkan fasilitas kerja memiliki pengaruh yang signifikan terhadap kepuasan kerja karyawan bagian pemetik teh di PT Perkebunan Tambi, Unit Perkebunan Tambi, Kabupaten Wonosobo karena t-Hitung $-0,140<\mathrm{t}$-Tabel 1,673 dan Sig. 0,889 serta dengan koefisien regresi -0,009. Artinya setiap penambahan fasilitas kerja akan mengurangi kepuasan kerja yang dirasakan karyawan. Penelitian ini tidak sejalan dengan penelitian Dahlius dan Ibrahim (2016) menyatakan bahwa "fasilitas kerja berpengaruh terhadap kepuasan kerja karyawan."

Kelengkapan fasilitas kerja yang disediakan perusahaan mempengaruhi seorang karyawan dalam melaksanakan pekerjaan sebagai pemetik teh. Fasilitas kerja adalah suatu alat dan bahan yang disediakan perusahaan dalam membantu pelaksanaan kerja karyawan (Husnan, 2002). Namun dalam hal ini, penambahan fasilitas kerja seperti perumahan menyebabkan kepuasan kerja karyawan berkurang karena karyawan merasa rumah yang disediakan perusahaan kurang tepat sasaran. Karyawan pemetik teh lebih memilih untuk tinggal dirumah sendiri dengan alasan tempat kerja dan rumah karyawan mudah dijangkau, meskipun dipaksakan justru hanya akan membuat karyawan merasa terbebani harus tinggal jauh dari keluarga.

\section{Pengaruh Lingkungan Kerja (X5) Terhadap Kepuasan Kerja Karyawan (Y)}

Secara parsial lingkungan kerja memiliki pengaruh yang signifikan terhadap kepuasan kerja karyawan bagian pemetik teh di PT Perkebunan Tambi, Unit Perkebunan Tambi, Kabupaten Wonosobo karena t-Hitung 2,363 > t-Tabel 1,673 dan Sig. 0,022<0,05 serta dengan koefisien regresi 0,234. Artinya semakin baik lingkungan tempat kerja yang dirasakan karyawan, maka akan memberikan dampak terhadap kepuasan kerja karyawan. Penelitian ini sejalan dengan penelitian Devino (2017) menyatakan bahwa "lingkungan kerja berpengaruh terhadap kepuasan kerja karyawan."

Lingkungan kerja merupakan suatu keada yang ada ditempat yang dapat mempengaruhi karyawan dalam melaksanakan pekerjaan (Nitisemito, 2002). Karyawan bagian pemetik teh di Unit Perkebunan Tambi merasa tempat mereka bekerja bersih yang membuat karyawan nyaman dalam melaksanaan kerja, rekan kerja bekerja sesuai dengan pembagian kerja masing-masing sehingga tidak terjadi masalah miskomunikasi sesama pekerja pemetik teh, rekan kerja yang saling membantu dan menghormati satu sama lain serta tempat kerja yang aman membuat karyawan merasa terlindungi. Devino (2017), menyatakan bahwa lingkungan kerja yang mendukung memungkinkan karyawan berkerja secara maksimal. 


\section{KESIMPULAN DAN SARAN}

\section{Kesimpulan}

Kesimpulan dalam penelitian ini menunjukkan bahwa karyawan merasa puas bekerja sebagai pemetik teh karena pekerjaan memberikan tantangan, upah yang diberikan sesuai dengan pekerjaan yang dilakukan, kondisi tempat yang mendukung, sesama rekan kerja saling mendukung dan menghormati satu sama lain serta jenis pekerjaan yang sesuai dengan keinginan karyawan. Variabel motivasi kerja $\left(\mathrm{X}_{1}\right)$, budaya organisasi $\left(\mathrm{X}_{2}\right)$ dan lingkungan kerja $\left(\mathrm{X}_{5}\right)$ memiliki pengaruh yang signifikan terhadap kepuasan kerja karyawan (Y). Sedangkan variabel gaya kepemimpinan $\left(\mathrm{X}_{3}\right)$ dan fasilitas kerja $\left(\mathrm{X}_{4}\right)$ tidak memiliki pengaruh yang signifikan terhadap kepuasan kerja karyawan $(\mathrm{Y})$ bagian pemetik teh di PT Perkebunan Tambi, Unit Perkebunan Tambi, Kabupaten Wonosobo.

\section{Saran}

Rekomendasi dalam penelitian ini sebagai berikut: Bagi PT Perkebunan Tambi, Unit Perkebunan Tambi, Kabupaten Wonosobo perlu meningkatkan gaya kepemimpinan terhadap bawahan dan memberikan fasilitas kerja yang lebih sesuai dengan kebutuhan karyawan sehingga dapat berdampak terhadap kepuasan kerja karyawan bagian pemetik teh. Bagi penelitian lebih lanjut menggunakan variabel penelitian kompensasi finansial dan non-finansial.

\section{DAFTAR PUSTAKA}

Arikunto, S. 2010. Prosedur Penelitian. [Jakarta (ID)]: Rineka Cipta.

Bangun, W. 2012. Manajemen Sumber Daya Manusia. [Jakarta (ID)]: Erlangga.

Badan Pusat Statistik. 2017. Statistik Teh Indonesia. [Internet]. [diunduh 15 Desember 2018]; Tersedia dari: https://www.bps.go.id/.

Badan Pusat Statistik. 2019. Produksi Teh Menurut Provinsi di Indonesia. [Internet]. [diunduh 15 Januari 2019]; Tersedia dari: https://www.bps.go.id/.

Brahmasari, I, A dan Suprayetno, A. 2008. Pengaruh Motivasi Kerja, Kepemimpinan dan Budaya Organisasi Terhadap Kepuasan Kerja Karyawan serta Dampaknya pada Kinerja Perusahaan (Studi kasus pada PT. Pei Hai International Wiratama Indonesia). Jurnal Manajemen Dan Kewirausahaan. $10(2): 124-135$.

Dahlius, A dan Ibrahim, M. 2016. Pengaruh Fasilitas Kerja Terhadap Kepuasan Kerja Karyawan Pada PT. Bank Riaukepri Cabang Teluk Kuantan Kabupaten Kuantan Singingi. Jurnal JOM FISIP. 3 (2):1-13.

Damanik, D, A. 2015. Analisis Faktor-Faktor Yang Mempengaruhi Produksi Teh (Studi Kasus: PTPN IV Bahbutong, Kec. Sidamanik, Kab. Simalungun Sumatera Utara). Jurnal Jom FEKON. 2 (2):1-15.

Devino, A, J. 2017. Pengaruh Motivasi, Lingkungan Kerja dan Kepuasan Kerja Terhadap Kinerja Karyawan Pada PT. Raja Indo di Makassar. [Skripsi]. [Makassar (ID)]: Universitas Hasanuddin Makassar. 
Faisal, S. 2007. Format-Format Penelitian Sosial. [Jakarta (ID)]: Raja Grafindo Persada.

Ghozali, I. 2012. Aplikasi Analisis Multivariate Dengan Program SPSS. [Semarang (ID)]: Badan Penerbit Universitas Diponegoro.

Handoko, H, T. 2002. Manajemen Personalia dan Sumber Daya Manusia. Edisi ke 2. [Yogyakarta (ID)]: BPFE UGM.

Hartono, A. 2018. Pengaruh Faktor Internal dan Eksternal Terhadap Kepuasan Kerja Karyawan Bagian Buruh Sadap Karet di PT. PTPN IX, Kebun Ngobo, Kabupaten Semarang. [Skripsi]. [Salatiga (ID)]: Universitas Kristen Satya Wacana.

Heriyanti, D. 2007. Analisis Pengaruh Budaya Organisasi, Kepuasan Kerja, dan Gaya Kepemimpinan Terhadap Kinerja Karyawan Dengan Komitmen Organisasional Sebagai Variabel Interverning (Studi PT. PLN (Persero) APJ Semarang). [Tesis]. [ Semarang (ID)]: Universitas Diponegoro.

Husnan, S. (2002). Dasar-Dasar Manajemen Keuangan. [Yogyakarta (ID)]: UPP AMP YKPN.

Lufitasari, R. 2014. Pengaruh Motivasi Kerja, Disiplin Kerja dan Kompensasi Terhadap Kinerja Karyawan Pada Dinas Pendapatan, Pengelolaan Keuangan dan Aset D. I. Yogyakarta. [Tugas Akhir]. [Yogyakrta (ID)]: Universitas Negeri Yogyakarta.

Mariam, R. 2009. Pengaruh Gaya Kepemimpinan dan Budaya Organisasi Terhadap Kinerja Karyawan Melalui Kepuasan Kerja Karyawan Sebagai Variabel Intervening Studi Pada Kantor Pusat PT. Asuransi Jasa Indonesia (Persero). [Tesis]. [Semarang (ID)]: Universitas Diponegoro.

Nazir, M. 2011. Metode Penelitian. [Jakarta (ID)]: Ghalia Indonesia.

Prasetiyo, S. 2014. Pengaruh Gaya Kepemimpinan dan Kompensasi Terhadap Kinerja Karyawan Dengan Kepuasan Kerja Sebagai Variabel Intervening (Studi Pada Hotel Berbintang Di Yogyakarta). [Skripsi]. [Yogyakarta (ID)]: Universitas Negeri Yogyakarta.

Priyatno, D. 2013. Mandiri Belajar Analisis Data Dengan SPSS. [Yogyakarta (ID)]: Mediakom.

Rakhmawati, D. 2008. Analisis Break Even Point Pada Usaha Pengolahan Pucuk Daun Teh (Kasus Di Pabrik Teh Sumber Daun Kabupaten Cianjur). [Skripsi]. [Surakarta (ID)]: Universitas Sebelas Maret Surakarta.

Sugiyono. 2013. Metode Penelitian Kuantitatif, Kualitatif dan R\&D. Cetakan Ke-19. [Bandung (ID)]: ALFABETA, CV.

Tambi, UP. 2019. Rencana Kerja dan Anggaran Perusahaan (RKAP) Unit Perkebunan Tambi. [Data Laporan Perusahaan]. [Diperoleh 30 Januari 2019 ]. Tersedia di PT Perkebunan Tambi, Unit Perkebunan Tambi.

Umar, H. 2005. Riset Sumber Daya Manusia Dalam Organisasi. Cetakan ketujuh. [Jakarta (ID)]: PT Gramedia Pustaka Utama. 